\title{
Credible Protein Targets and Curative Strategies for COVID-19: a Review
}

\author{
Priya Singh ${ }^{1} \cdot$ Nidhi Mishra ${ }^{1}$. Neelu Singh ${ }^{1} \cdot$ Raquibun Nisha $^{1} \cdot$ Ravi Raj Pal $^{1} \cdot$ Samipta Singh $^{1} \cdot$ Priyanka Maurya $^{1}$. \\ Shubhini A. Saraf ${ }^{2}$ (D)
}

Accepted: 16 September 2020 / Published online: 25 September 2020

(C) Springer Nature Switzerland AG 2020

\begin{abstract}
The pandemic of coronavirus infection 2019 (COVID-19) due to the serious respiratory condition created by the coronavirus 2 (SARS-CoV-2) presents a challenge to recognize effective strategies for management and treatment. In general, COVID-19 is an acute disease that can also be fatal, with an ongoing $10.2 \%$ case morbidity rate. Extreme illness may bring about death because of enormous alveolar damage and hemorrhage along with progressive respiratory failure. The rapidly expanding information with respect to SARS-CoV-2 research suggests a substantial number of potential drug targets. The most encouraging treatment to date is suggested to be with the help of remdesivir, hydroxychloroquine, and many such repurposed drugs. Remdesivir has a strong in vitro activity for SARS-CoV-2, yet it is not the drug of choice as affirmed by the US Food and Drug Administration and presently is being tried in progressing randomized preliminaries. The COVID-19 pandemic has been the worst worldwide general health emergency of this age and, possibly, since the pandemic influenza outbreak of 1918 . The speed and volume of clinical preliminaries propelled to examine potential treatments for COVID-19 feature both the need and capacity to create abundant evidence even in the center of a pandemic. No treatments have been demonstrated as accurate and dependable to date. This review presents a concise precise of the targets and broad treatment strategies for the benefit of researchers.
\end{abstract}

Keywords COVID-19 · SARS-CoV-2 $\cdot$ Protein targets $\cdot$ Antisense therapy $\cdot$ Repurposed drugs

\begin{tabular}{|c|c|}
\hline Abbreviations & \\
\hline COVID-19 & Coronavirus infectious disease 2019 \\
\hline SARS-CoV-2 & $\begin{array}{l}\text { Severe acute respiratory disorder } \\
\text { coronavirus } 2\end{array}$ \\
\hline US & United States \\
\hline HIV & Human immunodeficiency virus \\
\hline 2019-nCoV & 2019- coronavirus \\
\hline $\mathrm{HCoV}-229 \mathrm{E}$ & Human coronavirus $229 \mathrm{E}$ \\
\hline HCoV-NL6 & Human coronavirus NL6 \\
\hline HCoV-HKU1 & Human coronavirus HKU1 \\
\hline MERS-CoV & Middle East respiratory syndrome \\
\hline
\end{tabular}

This article is part of the Topical Collection on Covid-19

Shubhini A. Saraf

shubhini.saraf@gmail.com; sasaraf@bbau.ac.in

1 Department of Pharmaceutical Sciences, SB\&PS, Babasaheb Bhimrao Ambedkar University, Vidhyavihar, Raebareily Road, Lucknow, Uttar Pradesh, India

2 Department of Pharmaceutical Sciences, Babasaheb Bhimrao Ambedkar University, Vidya Vihar, Raebareli Road, Lucknow, U.P. 226025, India

$\begin{array}{ll}\text { HCoV-OC43 } & \text { Human coronavirus OC43 } \\ \text { CoV } & \text { Coronavirus } \\ \text { RNA } & \text { Ribonucleic acid } \\ \text { M protein } & \text { Membrane protein } \\ \text { E protein } & \text { Envelope protein } \\ \text { S protein } & \text { Spike protein } \\ \text { N protein } & \text { Nucleocapsid protein } \\ \text { HE } & \text { Hemagglutinin esterases } \\ \text { ACE2 } & \text { Angiotensin-converting enzyme 2 } \\ \text { TM } & \text { Trimeric } \\ \text { ED } & \text { Ectodomain } \\ \text { MHV-A59 } & \text { Mouse hepatitis virus strain A59 } \\ \text { SM } & \text { Small membrane protein } \\ \text { RBD } & \text { Receptor-binding domain } \\ \text { TMD } & \text { Transmembrane domain } \\ \text { HnRNPA-1 } & \text { Heterogeneous nuclear } \\ & \text { ribonucleoprotein A1 } \\ \text { M } & \text { Membrane proteases } \\ \text { 3CL } & \text { Cysteine-like protease } \\ \text { PLPro } & \text { Papain-like protease(s) } \\ \text { TGEV } & \text { Transmissible gastroenteritis virus }\end{array}$




$\begin{array}{ll}\text { Nsp } & \text { Non-structural protein } \\ \text { USPs } & \text { Ubiquitin-specific proteases } \\ \text { RMSD } & \text { Root-mean-square-deviation } \\ \text { HAUSPs } & \text { Monoclonal antibody for studying USP7 } \\ \text { BCV } & \text { Bovine coronavirus } \\ \text { BSM } & \text { Bovine submaxillary mucin } \\ \text { HCV-OC43 } & \text { Human coronavirus OC43 } \\ \text { Neu5-9Ac-2 } & \text { 9-O-acetyl-5- } N \text {-acetyl sialic acids } \\ \text { HEF-1 } & \text { Hemagglutinin esterases fusion protein } \\ \text { DNA } & \text { Deoxy ribonucleic acid } \\ \text { NTP } & \text { Nucleotide triphosphate } \\ \text { RSV } & \text { Respirational syncytial virus } \\ \text { vRNP } & \text { Viral nucleoproteins } \\ \text { CRM } & \text { Cellular export receptor } \\ \text { GTP } & \text { Guanosine triphosphate } \\ \text { ESCRT } & \text { Endosomal sorting complex } \\ & \text { required for transport } \\ \text { 3D } & \text { Three-dimensional } \\ \text { RAS } & \text { Renin-angiotensin system } \\ \text { ACEIs } & \text { Angiotensin-converting enzyme antagonists } \\ \text { ARBs } & \text { Angiotensin II type 1 receptor blockers } \\ \text { CT } & \text { Clinical trials } \\ \text { IL } & \text { Interleukin } \\ \text { mRNA } & \text { Messenger ribonucleic acid } \\ \text { PMO } & \text { Phosphorodiamidate morpholino oligomers } \\ \text { WHO } & \text { World health organization } \\ \text { ICMR } & \text { Indian council of medical research } \\ \text { ARDS } & \text { Acute respiratory distress syndrome } \\ \text { RT-PCR } & \text { Reverse transcription } \\ & \text { polymerase chain reaction } \\ \text { SiRNA } & \text { Small inhibitory ribonucleic acid } \\ \text { Symbols } & \\ \text { kb Kilobase } & \\ \text { nm Nanometer } \\ \text { kDa Kilodalton } \\ \text { A } \quad \text { Angstrom } \\ \end{array}$

\section{Introduction}

Corona virus at first probably surfaced in Wuhan, a city with a population of 11 million [1]. Coronavirus disease (COVID-19) is triggered via a novel coronavirus that leads to coughing, fever, and trouble in breathing. Symptoms may appear 56 days after infection. This virus rapidly spread worldwide, including China, Japan, the US, South Korea, Britain, Italy, and India. The confirmed cases of infection (COVID-19) are multiplying at an exponential rate as well as the death rates [2].

The COVID-19 is deadly and stands answerable for many deaths by a respiratory infection [3].

At present, no confirmed treatment for COVID-19 exists and the treatment for infection from COVID-19 is yet in its early stages, although the step is frantic. Some preliminary studies have investigated potential combinations that include anti-malarial drug chloroquine, drug ivermectin, and anti-HIV vaccines which may provide some relief against COVID-19 infections [4].

Phylogenetic analysis of this virus indicated that it is different ( $\sim 80 \%$ nucleotide identity) but related to SARS-CoV1. Because the world is threatened by the possibility of a SARS-CoV-2 pandemic, the broad-spectrum antiviral effects of chloroquine warranted particular attention for repurposing this drug in the therapy of the disease caused by SARS-CoV2, named coronavirus disease 2019 (COVID-19) [5].

\section{Scientific Categorization and Structure of Human Coronaviruses}

Coronaviruses are placed in two subfamilies; coronavirinae and torovirinae within the family of coronaviridae, which is contained in the order of nidovirales. The coronavirinae subfamily is characterized into four essential genera: alpha-coronavirus, beta-coronavirus, gamma-coronavirus, and delta-coronavirus as per the Worldwide Committee for Logical Classification of Infections [6]. COVID-19 affects mammals and is thought to spread from bats [7]. Coronaviruses include single-stranded positive-sense RNA infection through the biggest genome size, extending around 26-32 kb quantitated [8]. This genome is wrapped inside the helical capsid which is made up of the nucleohelical capsid protein. In these viral envelopes, there are three structural and functional proteins, i.e., the membrane protein (M), the envelope protein $(\mathrm{E})$, and the spike protein $(\mathrm{S})$. The membrane and envelope proteins help in wrapping the genome whereas the spike proteins mediate virus entry into host cells to infect the same. Some coronaviruses additionally encrypt an envelope-related hemagglutinin-esterase protein (HE) [9].

In these structural proteins, the spikes of the surface of the genome give coronaviruses the resemblance of a crown from outside hence named corona (Latin word) which means crown. The main functioning protein is spike (S) protein because it determines the range and immune responses of the host cells. The spikes of coronaviruses contain three segments: a large ectodomain, a single-pass transmembrane anchor, and a short intracellular tail. The S protein enters the human alveolar epithelial cells through binding angiotensinconverting enzyme 2 (ACE2) receptors [10-12].

India's first microscopic photos of the SARS-CoV-2 indicate that it is circular like other coronaviruses, around 70 $80 \mathrm{~nm}$ (a human hair is around $80,000 \mathrm{~nm}$ ), and has a cobbled surface layer [13].

\section{Protein Targets in the Structure of COVID-19}

Spike Protein The S protein is a clove-like type I TM protein. It has three fragments which are the ectodomain (ED) region, 
TM zone. Also, intracellular space comprises short tail fragments. The receptor restricting the $\mathrm{S} 1$ area (three $\mathrm{S} 1$ heads) and the layer combination subunit $\mathrm{S} 2$ (trimeric tail) on the $\mathrm{C}$ terminal, together, form the ED [14]. The ectodomain of all CoV spike proteins shares the same structure in two domains: an N-terminal domain called $\mathrm{S} 1$ which is responsible for receptor-binding and a fusion-related C-terminal S2 domain [15].

Spikes can be seen as simple, $20 \mathrm{~nm}$ elongated spherical surface projections on the virion membrane under an electron microscope [16]. Certain receptors can also mediate the entry of SARS-CoV-2 through T cells, such as CD147, on the surface of T lymphocytes, a novel intrusive path for SARS-CoV2 [17].

Membrane Protein SARS-CoV-2 reveals a $96 \%$ similarity to the bat coronavirus [18]. The mode of entry of the HIV1 is almost similar to that of coronavirus and both are able to fuse to the cell and elicit severe devastating effects [19].

The glycoprotein membrane (M) covers the viral envelope and has three regions, namely the cytoplasmic domain, the transmembrane dominion, and the membrane's hydrophilic end N. M protein is a glycoprotein largely responsible for making up viral particles and tiny membrane protein, used together to create a homogeneous matrix. Proteins like S, N, and $\mathrm{E}$ that associate with this protein form heterogeneous complexes. $\mathrm{M}$ protein alone cannot cause virion formation; it must be triggered until E protein acts so it can be formed into virions. The association between the virus and the host can be linked to $\mathrm{M}$ protein glycosylation [20].

Envelop Protein On studying the primary and secondary structures, it is revealed that $\mathrm{E}$ includes a little, hydrophilic amino end composed of 7-12 amino acids, with a wide hydrophobic transmembrane (TMD) space of 25 amino acids, and wraps up with a long hydrophilic carboxylic end containing the remaining portion of the protein [21].

$\mathrm{E}$ is disproportionately distributed inside the infected cell throughout the replication process but only a limited amount is integrated into the virion envelope [22]. Recombinant CoVs missing E show significantly decreased viral titers, weakened viral development, or awkward offspring for producing, outlining the centrality of $\mathrm{E}$ in infection advancement and development [23].

Studies reveal a significant portion of TMD consists of two non-polar, neutral amino acids, valine, and leucine, which offer the E protein a heavy hydrophobicity [24]. In both CoVs, membrane (M) and spike (S) proteins are the bulk of the protein found in the viral shell, although only a few E protein molecules are available [25].

Nucleocapsid Protein The nucleocapsid protein collaborates through hydrophilic and hydrophobic cooperations with the
RNA genome. Because 1500 nucleocapsid molecules are present per viral core and are assumed to cover the genome widely, each molecule will bind with average 11-12 nucleotide residues if equally spread [26]. N protein self-affiliation has been seen in numerous infections and is required to shape the viral capsid that shields the viral genome from extracellular agents [27].

The $\mathrm{N}$ protein is a $46-\mathrm{kDa}$ protein consisting of 422 amino acids [28]. Chang et al. (2006) conducted a biophysical experiment which indicated that this protein consisted of two distinct structural domains and a linking zone [29]. The first domain, within the putative RNA binding domain, is located at the $\mathrm{N}$-terminus. The second domain is the $\mathrm{C}$-terminal region capable of self-association [30].

Proteases The primary proteases $\left(\mathrm{M}_{\text {Pro }}\right.$ also named $\left.3 \mathrm{CL}_{\mathrm{Pro}}\right)$ are one of the better-described drug targets of coronaviruses. This enzyme is significant for the handling of the polyproteins that are translated from the viral RNA, alongside the papainlike protease(s) [31]. The $\mathrm{M}_{\text {Pro }}$ acts on the broad polyprotein1-ab (replicase-1-ab, $790 \mathrm{kDa}$ ) at no fewer than 11 cleavage sites; the sequence of identification at most locations is LeuGln replication (Ser, Ala, Gly) (marks the cleavage site). Halting this enzyme's function will prevent viral replication. Because no human proteases are reported to have a comparable cleavage range, inhibitors are unlikely to be harmful [32].

Given the substantial challenge faced by SARS-CoV and associated viruses, it is clear that the amount of cases so far does not justify the commercial production of a targeted antiviral medication [33].

3C-like Proteases Coronaviruses produce the largest documented RNA genome, varying in size from 27 to $32 \mathrm{~kb}$ for different $\mathrm{CoVs}$ and encoding a viral protease-processed replicase polyprotein, papain-like protease (PLP), and 3C-like protease (3CL $_{\text {Pro }}$, also documented as the central protease) [34]. The various available X-ray structures of the $3 \mathrm{C}$-like proteases from SARS-CoV, rhinoviruses, $\mathrm{HCoV}-229 \mathrm{E}$, and transmissible gastroenteritis infection (TGEV) render structure-based medicate plan reasonable [35].

All proteases are deemed promising targets for antiviral therapy, owing to their important function in viral replication [36] (Fig. 1).

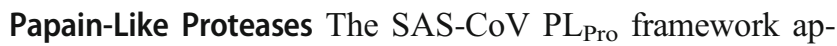
pears a design of thumb-palm-fingers coordinating cellular ubiquitin-specific proteases (USPs) [36]. SARS-CoV PLPro's dynamic location comprises of a canonical catalytic Cys-HisAsp group of three, near to that of USP14 [37].

The USPs are cysteine proteases forming strongly differing chains and show similarity primarily in the areas surrounding the catalytic Cys; these are the so-called Cys Box (B19 amino acids) and the His Box (60-90 amino acids) domains [38]. 


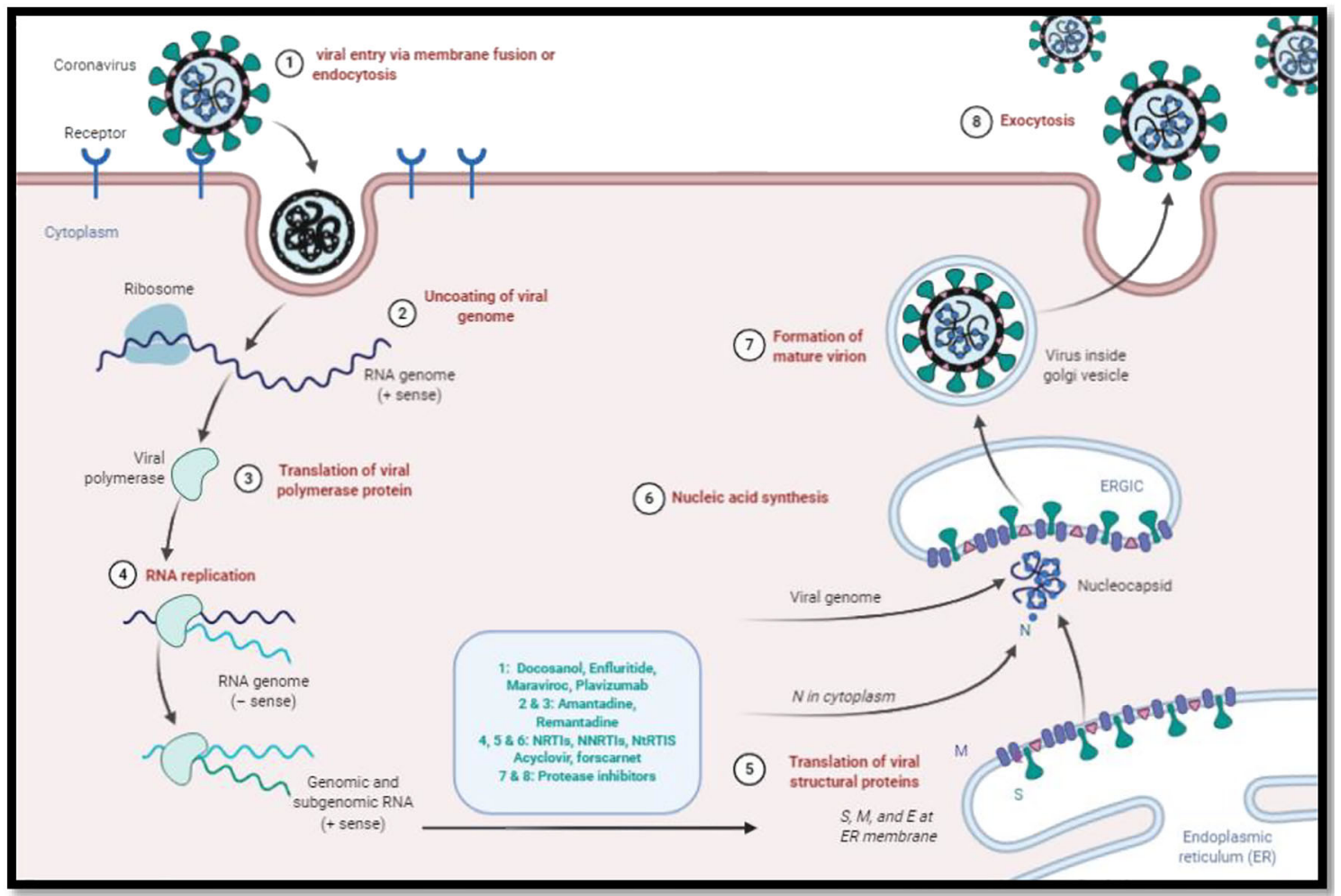

Fig. 1 Viral replication and their inhibitors

Hemagglutinin Esterase Hemagglutinin esterases (HEs) are a class of glycoproteins in the viral envelope that mediate reversible binding towards $O$-acetylated sialic acids by functioning as both lectins and receptor-destroying enzymes [39].

HE proteins of influenza infections, especially flu $\mathrm{C}$, were known to tie to cell receptors containing 9-O-acetyl-5- $\mathrm{N}$-acetyl sialic acids (Neu5, 9Ac2) as the significant receptor determinant [40].

Reports uncover that the CoV HE monomer comprises of three regions, each with a flu C HEF subunit 1 (HEF1) comparable: a receptor-binding space $(\mathrm{R})$, an acetyl esterase space $\mathrm{E}$, and a membrane-proximal space [41].

NTPase/Helicase Helicases are competent in enzymatically loosening up duplex DNA or RNA structures by disturbing the hydrogen bonds that keep the two strands together [42].

NS3 helicases are thought as a potential target for anticoronaviridae compounds [43]. NTPase/helicase (Hel) proteins are both known to be significant for the viability of nidoviruses and are thus possible targets for anti-SARS drug production [44].

Drug Targets for COVID-19 Antiviral medicines may be divided into fusion, non-coating, nucleic acid synthesis, absorption, and protease release inhibitors $[45,46]$.

Fusion/Entry The virus-host cell layer or receptor(s) relationship is the primary stage of the viral neurotic life arrangement, called the fusion/entry space. Advance fusion/entry inhibitors have been given for the administration of human immunodeficiency infection (HIV) and respirational syncytial infection (RSV) as a prophylactic measure. Targeting chemokine receptors and glycoprotein (GP)-receptor interactions, as important entry co-transporters are also among the most desirable candidates for viral entry/fusion inhibition [47].

$\mathrm{M}_{2}$ is a type III transmembrane protein forming tetramers whose transmembrane domains form a loop serving as a source of proton-selective ions. Opening the pores of the $\mathrm{M}_{2}$ ions acidifies the viral nucleus [48]. This acidic state in the virion releases the viral nucleoproteins (vRNP) from $M_{1}$ so that vRNP will reach the cytoplasm of the host cell-free [49].

Non-coating/Uncoating "Uncoating" diversely defines the removal of the structural proteins from the capsid. Furthermore, both the removal of structural proteins from the capsid and structural rearrangements within it can be called priming activities, since they are a requirement for effective release of the genome [50].

Nucleic Acid Synthesis The other approved antiviral drugs influenced the DDX3 (Asp-Glu-Ala-Asp (DEAD)-box polypeptide 3. DDX3 executes important steps in the metabolism of RNA which includes encoding, translation, and production of membranes stress granules. DDX3 is also involved in the in-built response of the body in case of viral invasions. Interestingly, certain RNA viruses, for example, HCV and 
HIV-1, use DDX3 to execute various phases of the replication processes [51].

Maturation and Release After de novo synthesis of viral genome and proteins, viral proteins are assembled into new viruses that are ready for release from the host cell with freshly replicated viral genome. This phase is referred to as maturation. vRNPs tend to be transported inside the nucleus through the nuclear pores through the CRM1-based pathway. Nucleoprotein appears to connect with CRM1 although there is no identification of GTP hydrolysis behavior. This suggests an uncommon export process if the transfer of vRNPs is essential in connecting NP to CRM1 [52]. The endosomal sorting complex necessary for the transport pathway (ESCRT) is a cellular system for the external budding and fission of vesicles away from the cytoplasm [53].

Drug Repurposing Drug repurposing from existing licensed products is a successful product development technique, which could shorten the period and lower costs relative to de novo product investigation [54].

This strategy provides numerous advantages over the creation of a specific indication of a completely new drug. The reused medication has already been indicated to be reasonably secure in preclinical models as well as in human studies, and since the early-stage study has already been completed, the chance of failing is lower and possibly most significantly, as, in subsequent efficacy trials, it is less probable at least from a side effect or toxicity point of view that it fails [55]. Second, the timeline for drug expansion can be shortened, because much of the preclinical testing, safety evaluation, and, in some cases, development of the formulation may have already been completed. Thirdly, less investment is required, although this may differ greatly depending on the repurposed candidate's stage and phase of development [56].

The detection of novel drug-disease interfaces is the main concern of medication repositioning. A variety of methodologies have been established to challenge this problem including quantitative strategies, biological strategies, and many more permutations and combinations of experimental strategies [57]. Most current computational strategies are centered on the quality expression reaction of cell lines after treatment or combining numerous shapes of information around a hypothesis [58].

However, novel product repurposing methods are expensive and time-consuming. Computational methods deliver new, testable theories for repositioning systemic drugs. Orthodox structure-based approaches are therefore restricted where three-dimensional (3D) protein structures are inaccessible, as is sadly the case with most human and viral targets. Furthermore, attacking single virus proteins also poses a high risk of drug resistance through rapidly changing virus genomes [59-61].
Drug Repurposing Challenges Drug repurposing presents the following challenges:

1. Intellectual property and economic considerations

2. Data and compound availability

3. Overcrowding of repurposing space [62].

Drugs Used in the Treatment of COVID-19 Infection An antiviral medication, Tamiflu, is targeted at inhibiting the enzyme that cleaves sialic acid on the exterior of human cells and thereby interferes with the capacity of the virus to enter the host. Newer medications, currently in clinical testing for the diagnosis of COVID-19 infection, such as chloroquine which is a well-known anti-malarial medication, and its variant hydroxychloroquine have shown better efficacy [4] (Table 1).

ACE2 has been reported to be the 2019-nCoV key host cell receptor and plays a critical role in a viral entry inside the cell to induce the infection. To explore the possible route of 2019nCoV attack on oral cavity mucosa, bulk RNA-sequence profiling has been undertaken [69].

Renin-angiotensin framework (RAS) dysfunction has been recognized in patients enduring from coronavirus disease (COVID-19), but whether RAS antagonists, such as angiotensin-converting protein opponents (ACEIs) and angiotensin II sort 1 receptor blockers (ARBs), are connected with clinical impacts, however, remains vague [70]. The awareness of MERS-CoV and SARS-CoV immunotherapies in recent years may expand prospects for the successful use of the same treatments for modern coronavirus [71] [72].

Antisense Therapy In 1978, Zamecnik and Stephenson discovered the ability of oligodeoxynucleotides to function as antisense agents inhibiting viral repetition in cell culture [73]. The idea behind it is that the base of an antisense nucleic acid sequence pairs with its complementary sense RNA strand and evades its conversion into a protein. By attaching to mRNA, antisense drugs disrupt and interfere with the development of different proteins associated with the diseases [74].

The basic principle is that whenever an oligonucleotide (a short RNA or DNA molecule complementary to an agencygenerated mRNA) may be inserted into a cell, it can precisely attach to its target mRNA by the excellent specificity of complementary base pairing the same process that guarantees the gene's adherence to DNA replication and RNA transcription. This attachment creates an RNA dimer in the cytoplasm and prevents the synthesis of proteins [75]. Reports indicate that the role of cyclodextrin derivatives as a transferor for the transmission of phosphodiester oligonucleotides in viral infections could be an important strategy for improving the therapeutic ability of such compounds. Viral infections can occur when the oligonucleotides in the antisense complement viral RNAs [76]. Many antisense medications have reached clinical 
Table 1 Repurposed drugs in COVID-19 infections

\begin{tabular}{|c|c|c|c|}
\hline Drug & Therapeutic use & The original mode of action & Being tested? \\
\hline Chloroquine & Anti-malarial & Heme-polymerase inhibitor & Under clinical trials \\
\hline Kaletra (ritonavir and lopinavir) & HIV & Protease inhibitor & Yes \\
\hline Interferon alfa- $2 b$ & Hepatitis C & Immune modulator & Under clinical trials \\
\hline Remdesivir & Experimental & Nucleotide analog & Approved \\
\hline Favipiravir & Influenza & RNA polymerase inhibitor & Yes \\
\hline Actemra [63] (tocilizumab) & Rheumatoid arthritis; COVID-19 & Anti-inflammatory & Yes \\
\hline Kevzara (sarilumab) & Rheumatoid arthritis & Anti-inflammatory & Yes \\
\hline Rapamycin & Anti-tumor & Immunosuppressant & Yes \\
\hline Arbidol [64] & Antiviral & Fusion inhibitor & Under CT \\
\hline Thymosin [63] & Immunotherapy & Polypeptide hormone for the maturation of $\mathrm{T}$ cells & Yes \\
\hline Siltuximab [63] & COVID-19 & Against interleukins-6 receptor (IL-6R) & Yes \\
\hline Sofosbuvir & Hepatitis virus $\mathrm{C}$ & Viral RNA synthesis inhibitor & Under CT \\
\hline IDX-184 [65] & Immunotherapy & Lymphokine-activated killer cells & $\mathrm{CT}$ \\
\hline Ribavirin [66] & Broad-acting antiviral drugs & Nucleoside inhibitor & $\mathrm{CT}$ \\
\hline Thymopentin [67] & Hepatitis B & Immunostimulants & Not approved \\
\hline Levamisole & Anti-parasitic agent & Polypeptide hormone for the maturation of $\mathrm{T}$ cells & Yes \\
\hline Cinanserin & Serotonin receptor antagonist & Replication inhibitor & Yes \\
\hline Emodin & Anti-SARS-CoV & $\mathrm{S}$ protein interactions & $\mathrm{CT}$ \\
\hline Promazine & Antipsychotic agents & Replication inhibitor & Yes \\
\hline Nitric oxide & Anti-inflammatory agent & Viral RNA synthesis inhibitor & $\mathrm{CT}$ \\
\hline Mucroporin M1 & Broad-spectrum antiviral agents & COVID-19 & Yes \\
\hline Estradiol and phytoestrogen & Immunotherapy & Potent MERS-CoV & Yes \\
\hline Melatonin [68] & Anti-oxidants & Activation of melanin receptors & $\mathrm{CT}$ \\
\hline
\end{tabular}

trials during the last 30 years for the prevention of a large range of diseases. Fomivirsen is a first-generation antisense cytomegalovirus medication approved for the treatment of cytomegalovirus retinitis, a serious opportunistic infection in HIV patients at the time [77]. Phosphorodiamidate morpholino-oligomers (PMO) and $\beta$-cyclodextrins are the main antisense agents that are used in the coronavirus infection [78] (Fig. 2).
Plasma Therapy The wellbeing network over the world is taking aid of plasma or immunizer treatment to fight COVID-19 [79] (Fig. 3). According to the WHO, the experience in the past suggests that the experimental use of convalescent plasma can be a possibly useful treatment for COVID-19. In India, numerous states have looked for and gotten the endorsement of ICMR for plasma treatment. Be that as it may, up until this point,
Fig. 2 Antisense therapy mechanism on COVID-19 infection

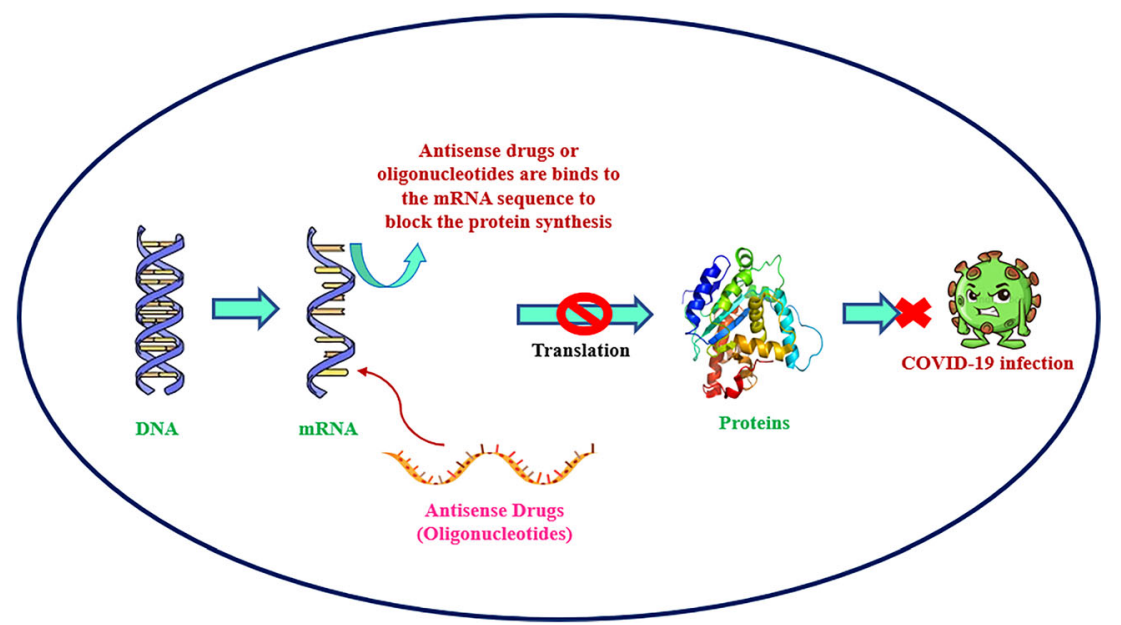


Fig. 3 Plasma therapy for COVID-19 patients

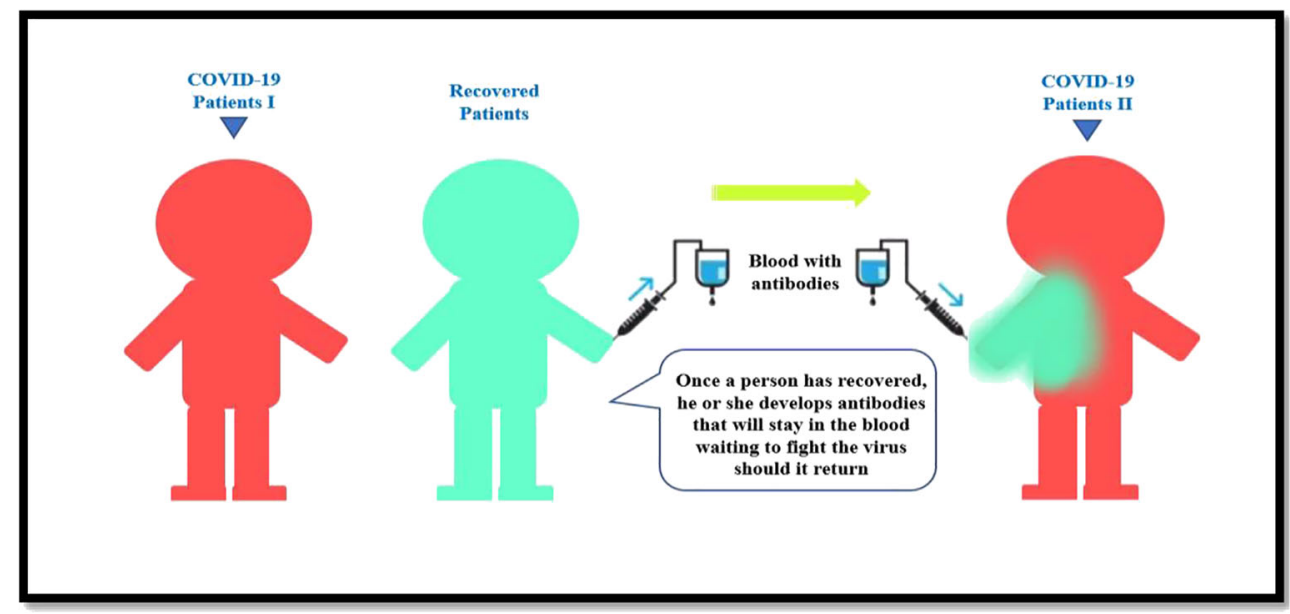

ICMR does not suggest it as a treatment alternative outside clinical trials [80].

\section{Discussion}

The basic protein and drug targets for COVID-19, which help in the systemic identification of putative repurposable medications and medication mixes for treatment of 2019nCoV/SARS-CoV-2, have been detailed above [54]. Two drugs, namely hydroxychloroquine and remdesivir, as well as steroids are the front runners in the quest for treatment for COVID-19 infection [81]. At this moment, our knowledge of the 2019-nCoV infection clinical framework is very restricted. Complications such as extraordinary pneumonia, respiratory distress where fluid accumulates in the lungs, and cardiac arrest are a few symptoms which have been recorded in patients all over the world. A few unspecific signs and indications of gentle illness early within the 2019-nCoV contamination similar to numerous other respiratory disorders, especially amid the winter respiratory infection season and related mild diseases, make it difficult to identify a patient [11]. The cases of asymptomatic patients also exist. Asymptomatic individuals disclose mishaps of sense of smell which is perhaps a sign [82].

If one gets to know that he/she has been in touch with an asymptomatic carrier of the disease, one must quarantine him/ herself for 14 days, without any delay. This will ensure that one does not spread the virus to others [83]. Agents targeting host signaling pathways or receptors may induce immunopathology [59].

At the active site of COVID-19, the numerous drug candidates with proven properties such as anti-malarial, anti-hepatitis $\mathrm{C}$, anti-bacterial, anti-fungal, and antiinflammatory have also been identified to be attached. The medicines retained unbonded associations with metabolites from the active site [84]. We discussed numerous mechanism demonstrating the significance of target sites in developing potential new therapies and developing new vaccines [85]. In the meantime, several antiviral drugs are being launched that have close properties to target 2019-nCoV single-stranded RNA and may serve as potential candidates for further research against 2019-nCoV [86].

\section{Conclusion}

The HCVs are smart enough to use the human physiological system to enter, multiply, show pathological symptoms, and then go on to utilize other human hosts to multiply and proliferate. Such rapid and efficient transmission is making it virtually impossible for humans to intervene and disrupt the life cycle of the virus. Even after vast-concentrated research and utilization of different methods to date, no effective treatment for $\mathrm{HCoVs}$ is available.

One of the key explanations for these is that for in vitro and in vivo research, most of the established agents have not been adequately evaluated. The main challenge is the race against time in this case, but eventually, this large body of research shall help us in the future to tackle any other types of coronaviruses that may emerge.

\section{Compliance with Ethical Standards}

Conflict of Interest The authors declare that they have no conflicts of interest.

Ethical Approval Not applicable.

Informed Consent No clinical trials were involved, hence not applicable. 


\section{References}

1. Cao Y, Deng Q, Dai S. Remdesivir for severe acute respiratory syndrome coronavirus 2 causing COVID-19: an evaluation of the evidence. Travel Med Infect Dis. 2020:101647.

2. Dong L, Hu S, Gao J. Discovering drugs to treat coronavirus disease 2019 (COVID-19). Drug Discov Ther. 2020;14(1):58-60.

3. Chhikara BS, Rathi B, Singh J, FNU P. Coronavirus SARS-CoV-2 disease COVID-19: infection, prevention and clinical advances of the prospective chemical drug therapeutics: a review on corona virus disease COVID-19, epidemiology, prevention, and anticipated therapeutic advances. Chem Biol Lett. 2020;7(1):63-72.

4. Beck BR, Shin B, Choi Y, Park S, Kang K. Predicting commercially available antiviral drugs that may act on the novel coronavirus (2019-nCoV), Wuhan, China through a drug-target interaction deep learning model. bioRxiv. 2020:2020.01.31.929547.

5. Devaux CA, Rolain J-M, Colson P, Raoult D. New insights on the antiviral effects of chloroquine against coronavirus: what to expect for COVID-19? Int J Antimicrob Agents, no. December 2019. 2020:105938.

6. Pillaiyar T, Meenakshisundaram S, Manickam M. Recent discovery and development of inhibitors targeting coronaviruses. Drug Discov Today. 2020;00(00).

7. Woo PCY, et al. Discovery of seven novel mammalian and avian coronaviruses in the genus Deltacoronavirus supports bat coronaviruses as the gene source of Alphacoronavirus and Betacoronavirus and avian coronaviruses as the gene source of Gammacoronavirus and; 2012. p. 3995-4008.

8. Coronaviruses BI. crossm. 2019;93(12):1-15.

9. Maxson, Mitchell. HHS public access. Physiol Behav. 2016;176(1):139-48.

10. Yang Y, Islam MS, Wang J, Li Y, Chen X. Traditional Chinese medicine in the treatment of patients infected with 2019-new coronavirus (SARS-CoV-2): a review and perspective. Int J Biol Sci. 2020;16(10):1708-17.

11. Holshue ML, DeBolt C, Lindquist S, Lofy KH, Wiesman J, Bruce $\mathrm{H}$, et al. First case of 2019 novel coronavirus in the United States. N Engl J Med. 2020;382(10):929-36.

12. Vinet $\mathrm{L}$, Zhedanov A. Fast identification of possible drug treatment of coronavirus disease -19 (COVID-19) through computational drug repurposing study Junmei. Clim Chang 2013 - Phys Sci Basis. 2010;8(9):1-30.

13. Delhi NEW, Journal I, Sciences M. India's 1st corona images show it' $s$ round with cobbled surface; 2020. p. 1-2.

14. Kumar N, et al. Characterization of Rubia cordifolia L. root extract and its evaluation of cardioprotective effect in Wistar rat model. Indian J Pharmacol. 2018;49(5):344-7.

15. Belouzard S, Millet JK, Licitra BN, Whittaker GR. Mechanisms of coronavirus cell entry mediated by the viral spike protein. Viruses. 2012;4(6):1011-33.

16. Siebert DN. Análise de formas discretas da equação de Boltzmann para problemas térmicos bi-dimensionais. 2007;77(16):8801-11.

17. Wang $\mathrm{X}$, et al. SARS-CoV-2 infects T lymphocytes through its spike protein-mediated membrane fusion," no. March; 2020. p. 2 4.

18. Velavan TP, Meyer CG. The COVID-19 epidemic. 2020;25(3): 278-80.

19. Tong TR. Drug targets in severe acute respiratory syndrome ( SARS ) virus and other coronavirus infections; 2009. p. 223-45.

20. Pang J, et al. Potential rapid diagnostics, vaccine and therapeutics for 2019 novel coronavirus (2019-nCoV): A Systematic Review. J Clin Med. 2020;9(3):623.
21. Schoeman D, Fielding BC. Coronavirus envelope protein: current knowledge. Virol J. 2019;16(1):1-22.

22. Venkatagopalan P, Daskalova SM, Lopez LA, Dolezal KA, Hogue BG. Coronavirus envelope ( $\mathrm{E}$ ) protein remains at the site of assembly. Virology. 2015;478:75-85.

23. DeDiego ML, Álvarez E, Almazán F, Rejas ḾT, Lamirande E, Roberts A, et al. A severe acute respiratory syndrome coronavirus that lacks the $\mathrm{E}$ gene is attenuated in vitro and in vivo. J Virol. 2007;81(4):1701-13.

24. Vankadari N, Wilce JA. Emerging WuHan (COVID-19) coronavirus: glycan shield and structure prediction of spike glycoprotein and its interaction with human CD26. Emerg. Microbes Infect. 2020;9(1):601-4.

25. Vennemal $\mathrm{H}$, et al. Nucleocapsid-independent assembly of coronavirus-like particles by co-expression of viral envelope protein genes. 2020;15(8):2020-8.

26. Muriaux D, Darlix JL. Properties and functions of the nucleocapsid protein in virus assembly. RNA Biol. 2010;7(6):744-53.

27. McBride R, van Zyl M, Fielding BC. The coronavirus nucleocapsid is a multifunctional protein. Viruses. 2014;6(8):2991-3018.

28. Surjit M, Lal SK. The SARS-CoV nucleocapsid protein: a protein with multifarious activities. Infect Genet Evol. 2008;8(4):397-405.

29. Lau SKP, Woo PCY, Wong BHL, Tsoi HW, Woo GKS, Poon RWS, et al. Detection of severe acute respiratory syndrome (SARS) coronavirus nucleocapsid protein in SARS patients by enzyme-linked immunosorbent assay. J Clin Microbiol. 2004;42(7):2884-9.

30. Fang X, et al. Nucleocapsid amino acids 211 to 254, in particular, tetrad glutamines, are essential for the interaction between the nucleocapsid and membrane proteins of SARS-associated coronavirus. J Microbiol. 2006;44(5):577-80.

31. Zhang L, et al. Crystal structure of SARS-CoV-2 main protease provides a basis for design of improved $\alpha$-ketoamide inhibitors. 2020;3405(March):1-9.

32. L. Zhang et al., " $\alpha$ - Ketoamides as broad-spectrum inhibitors of coronavirus and enterovirus replication: structure-based design, synthesis, and activity assessment," 2020.

33. Van Der Hoek L, et al. Identification of a new human coronavirus. Nat Med. 2004;10(4):368-73.

34. Deng X, StJohn SE, Osswald HL, O'Brien A, Banach BS, Sleeman $\mathrm{K}$, et al. Coronaviruses resistant to a $3 \mathrm{C}$-like protease inhibitor are attenuated for replication and pathogenesis, revealing a low genetic barrier but high fitness cost of resistance. J Virol. 2014;88(20): 11886-98.

35. Grum-Tokars V, Ratia K, Begaye A, Baker SC, Mesecar AD. Evaluating the 3C-like protease activity of SARS-coronavirus: recommendations for standardized assays for drug discovery. Virus Res. 2008;133(1):63-73.

36. Mielech AM, Chen Y, Mesecar AD, Baker SC. Nidovirus papainlike proteases: multifunctional enzymes with protease, deubiquitinating and deISGylating activities. Virus Res. 2014;194:184-90.

37. Ratia K, Saikatendu KS, Santarsiero BD, Barretto N, Baker SC, Stevens RC, et al. Severe acute respiratory syndrome coronavirus papain-like-protease: structure of a viral deubiquitinating enzyme. Proc Natl Acad Sci U S A. 2006;103(15):5717-22.

38. Hu M, Li P, Song L, Jeffrey PD, Chenova TA, Wilkinson KD, et al. Structure and mechanisms of the proteasome-associated deubiquitinating enzyme USP14. EMBO J. 2005;24(21):3747-56.

39. Q. Zeng, M. A. Langereis, A. L. W. Van Vliet, E. G. Huizinga, and R. J. De Groot, "Structure of coronavirus hemagglutinin-esterase offers insight into corona and influenza virus evolution," no. 7, 2008. 
40. Klausegger A, Strobl B, Regl G, Kaser A, Luytjes W, Vlasak R. Identification of a coronavirus hemagglutinin-esterase with a substrate specificity different from those of influenza $\mathrm{C}$ virus and bovine coronavirus. J Virol. 1999;73(5):3737-43.

41. De Groot RJ. Structure, function and evolution of the hemagglutinin-esterase proteins of corona- and toroviruses. Glycoconj J. 2006;23(1-2):59-72.

42. Borowski P, Niebuhr A, Mueller O, Bretner M, Felczak K, Kulikowski T, et al. Purification and characterization of West Nile virus nucleoside triphosphatase (NTPase)/helicase: evidence for dissociation of the NTPase and helicase activities of the enzyme. J Virol. 2001;75(7):3220-9.

43. Briguglio I, Piras S, Corona P, Carta A. Inhibition of RNA helicases of ssRNA + virus belonging to Flaviviridae, Coronaviridae and Picornaviridae families. Int J Med Chem. 2011;2011:1-22.

44. Zhou J, Fang L, Yang Z, Xu S, Lv M, Sun Z, et al. Identification of novel proteolytically inactive mutations in coronavirus 3C-like protease using a combined approach. FASEB J. 2019;33(12):1457587.

45. Antonelli G, Turriziani O. Antiviral therapy: old and current issues. Int J Antimicrob Agents. 2012;40(2):95-102.

46. Pommier Y, Johnson AA, Marchand C. Integrase inhibitors to treat HIV/AIDS. Nat Rev Drug Discov. 2005;4(3):236-48.

47. Pour PM, Fakhri S, Asgary S, Farzaei MH, Echeverría J. The signaling pathways, and therapeutic targets of antiviral agents: focusing on the antiviral approaches and clinical perspectives of anthocyanins in the management of viral diseases. Front Pharmacol. 2019;10(November): $1-23$.

48. Samji T. Influenza a: understanding the viral life cycle. Yale J Biol Med. 2009;82(4):153-9.

49. Pinto LH, Lamb RA. The M2 proton channels of influenza a and B viruses. J Biol Chem. 2006;281(14):8997-9000.

50. Kilcher S, Mercer J. DNA virus uncoating. Virology. 2015;479480:578-90.

51. Ellis BRADTB. The enigma of yellow fever in East Africa. Rev Med Virol. 2009;19(1):57-64.

52. Shapiro GI, Gurney T, Krug RM. Influenza virus gene expression: control mechanisms at early and late times of infection and nuclearcytoplasmic transport of virus-specific RNAs. J Virol. 1987;61(3): 764-73.

53. Henne WM, Buchkovich NJ, Emr SD. The ESCRT pathway. Dev Cell. 2011;21(1):77-91.

54. Zhou Y, Hou Y, Shen J, Huang Y, Martin W, Cheng F. Networkbased drug repurposing for novel coronavirus 2019-nCoV/SARSCoV-2. Cell Discov. 2020;6(1).

55. Pushpakom S, Iorio F, Eyers PA, Escott KJ, Hopper S, Wells A, et al. Drug repurposing: Progress, challenges and recommendations. Nat Rev Drug Discov. 2018;18(1):41-58.

56. Breckenridge A, Jacob R. Overcoming the legal and regulatory barriers to drug repurposing. Nat Rev Drug Discov. 2018;18(1): $1-2$.

57. Martinez MA. Compounds with therapeutic potential against novel respiratory 2019 coronavirus. Antimicrob Agents Chemother. 2020;(March):1-18.

58. Napolitano F, et al. Drug repositioning: a machine-learning approach through data integration. J Cheminform. 2013;5(6):1-9.

59. Zumla A, Chan JFW, Azhar EI, Hui DSC, Yuen KY. Coronaviruses-drug discovery and therapeutic options. Nat Rev Drug Discov. 2016;15(5):327-47.

60. Cheng F. In silico oncology drug repositioning and polypharmacology. Methods Mol Biol. 2019;1878:243-61.
61. Cheng F, Murray JL, Rubin DH. Drug Repurposing: New Treatments for Zika Virus Infection? Trends Mol Med. 2016;22(11):919-921.

62. Talevi A, Bellera CL. Expert opinion on drug discovery challenges and opportunities with drug repurposing : finding strategies to find alternative uses of therapeutics. Expert Opin Drug Discov. 2020;15(4):397-401.

63. AminJafari A, Ghasemi S. The possible of immunotherapy for COVID-19: a systematic review. Int Immunopharmacol. 2020;83(March):106455.

64. Amanat Fatima KF. SARS-CoV-2 vaccines: status report. Cell. 2020:1-7.

65. Elfiky AA. Anti-HCV, nucleotide inhibitors, repurposing against COVID-19. Life Sci. 2020;248:117477.

66. Kandeel M, Al-Nazawi M. Virtual screening and repurposing of FDA approved drugs against COVID-19 main protease. Life Sci. 2020;251(March):117627.

67. Zhang L, Liu Y. Potential interventions for novel coronavirus in China: a systematic review. 2020;92(5).

68. Zhang R, Wang X, Ni L, di X, Ma B, Niu S, et al. COVID-19: melatonin as a potential adjuvant treatment. Life Sci. 2020;250: 117583.

69. $\mathrm{Xu} \mathrm{H}$, et al. High expression of ACE2 receptor of 2019-nCoV on the epithelial cells of oral mucosa. Int J Oral Sci. 2020;12(1):1-5.

70. Meng J, Xiao G, Zhang J, He X, Ou M, Bi J, et al. Reninangiotensin system inhibitors improve the clinical outcomes of COVID-19 patients with hypertension. Emerg. Microbes Infect. 2020;9(1):757-60.

71. Shanmugaraj B, Siriwattananon K, Wangkanont K, Phoolcharoen W. Perspectives on monoclonal antibody therapy as potential therapeutic intervention for coronavirus disease-19 (COVID-19). Asian Pacific J Allergy Immunol. 2020;38(1):10-8.

72. Tian X, Li C, Huang A, Xia S, Lu S, Shi Z, et al. Potent binding of 2019 novel coronavirus spike protein by a SARS coronavirusspecific human monoclonal antibody. Emerg Microbes Infect. 2020;9(1):382-5.

73. Kurreck J. Antisense technologies: improvement through novel chemical modifications. Eur J Biochem. 2003;270(8):1628-44.

74. S. Gupta, R. P. Singh, N. Rabadia, G. Patel, and H. Panchal, "Review article ANTISENSE TECHNOLOGY 1," vol. 9, no. 2, 2011.

75. Re R. Under the Microscope The Application of Antisense Technology. 2000;2(4):233-6.

76. Abdou S, Collomb J, Sallas F, Marsura A, Finance C. Betacyclodextrin derivatives as carriers to enhance the antiviral activity of an antisense oligonucleotide directed toward a coronavirus intergenic consensus sequence. Arch Virol. 1997;142(8):1585602 .

77. Bennett CF, Baker BF, Pham N, Swayze E, Geary RS. Pharmacology of antisense drugs. Annu Rev Pharmacol Toxicol. 2017;57(1):81-105.

78. Neuman BW, Stein DA, Kroeker AD, Paulino AD, Moulton HM, Iversen PL, et al. Antisense morpholino-oligomers directed against the $5^{\prime}$ end of the genome inhibit coronavirus proliferation and growth. J Virol. 2004;78(11):5891-9.

79. "Watch | Convalescent plasma therapy for COVID-19 patients India to explore plasma therapy for COVID-19 treatment," pp. 4 6, 2020.

80. Cheng Y, Wong R, Soo YOY, Wong WS, Lee CK, Ng MHL, et al. Use of convalescent plasma therapy in SARS patients in Hong Kong. Eur J Clin Microbiol Infect Dis. 2005;24(1):44-6.

81. Zheng J. SARS-CoV-2: an emerging coronavirus that causes a global threat. Int J Biol Sci. 2020;16(10):1678-85. 
82. Practice BB. Coronavirus disease 2019. World Heal Organ. 2019, 2020;(March):2633.

83. Tips F, News H, All S. Asymptomatic coronavirus : All about what it is and if it can be identified, vol. 12;2020. p. 1-8.

84. V. Balakrishnan and K. Lakshminarayanan, "Screening of FDA approved drugs against COVID-19 main protease : coronavirus disease," no. April, pp. 2-9, 2020.

85. Watanabe Y, et al. Vulnerabilities in coronavirus glycan shields despite extensive glycosylation. bioRxiv. 2020: 2020.02.20.957472.
86. M. V Yezhelyev, X. Gao, Y. Xing, A. Al-hajj, S. Nie, and R. M. O. Regan, "Emerging use of nanoparticles in diagnosis and treatment of breast cancer," 2006.

We the undersigned declare that the manuscript is original, has not been published before, and is not currently being considered for publication elsewhere.

Publisher's Note Springer Nature remains neutral with regard to jurisdictional claims in published maps and institutional affiliations. 